\title{
Defining Energy Security in the Rural North - Historical and Contemporary Perspectives from Alaska
}

\author{
Authors: \\ Yasmeen Hossain ${ }^{a^{*}} /$ yhossain@alaska.edu \\ Philip A. Loring ${ }^{b}$ / phil.loring@usask.ca \\ Tom Marsikc / tmarsik@alaska.edu \\ a University of Alaska Fairbanks, 505 S. Chandlar Drive, Fairbanks, AK 99775, US \\ ${ }^{b}$ University of Saskatchewan, 117 Science Place, Saskatoon, SK S7N 5C8, Canada \\ ' University of Alaska Fairbanks - Bristol Bay Campus, 527 Seward Stre \\ et, Dillingham, AK 99576, US \\ * Corresponding author \\ Yasmeen Hossain \\ 39 Winter St. \\ Northfield, VT 05663 \\ yhossain@alaska.edu
}




\title{
Defining Energy Security in the Rural North - Historical and Contemporary Perspectives from Alaska
}

\begin{abstract}
In this paper we discuss the historical dimensions of energy in rural Alaska to argue that energy security in rural locations involves different considerations than in urban areas, and as such a definition of energy security needs to be downscaled to a place-based perspective, addressing individual and household needs as opposed to national issues of supply, consumption, and distribution. The definition of energy security for local communities that we propose is adapted from the food security literature: having sufficient access to energy generation or provisioning services to conduct a sustainable life. Also similar to the food security literature, the framework we propose includes four dimensions to energy security: availability, access, quality, and stability. This paper applies the proposed definition and framework to the example of rural Alaska. Alaska has an abundance of energy sources, from oil and gas to a host of renewables, however due to colonial legacies, lack of infrastructure, policies and social structure a number of communities in rural Alaska struggle with energy insecurity.
\end{abstract}

\section{Keywords}

Energy Security, Rural Alaska, Food Security, Environmental Security, Indigenous Alaskan energy usage

\section{Introduction}

Energy security is an oft-discussed but rarely elaborated upon component of environmental security and community sustainability [i, ii]. Its importance has been elevated by research on the so-called food-water-energy nexus [i, iii], but questions remain regarding what exactly constitutes energy security at the household, community, or regional level, as compared to global and national levels where energy security primarily involves whether state governments have control over their energy generation and provisioning resources [ii,iv, v, vi, vii]. Like its counterparts in the nexus, energy security has different meanings depending on the level and location of analysis; energy security in rural areas often involves different features than in urban ones, and household and community energy security have little in common with energy security when construed in a militaristic or statist sense. For a rural community, energy security can mean resilience and self-sufficiency through an escape from the global carbon "lock in" [viii]; for an individual, it may well mean something as simple as being able to survive a cold winter or having a light at home so that children can study at night [ix, $\mathrm{x}]$.

Sovacool and Brown [iv] argue that energy security may ultimately prove to be the most important component of human environmental security, in that energy influences so many different aspects of people's lives, including food production and the distribution and treatment of drinking water. As was the case for making progress on food security research and policy [xi], we argue that new place-based perspectives are needed on energy security that scale down focus to the issues facing individuals, their households and livelihoods. As we describe below, this means paying attention to such diverse issues as breaking out of historical legacies of colonialism and development and the political ecology of energy resources [xii, xiii].

In this paper we illustrate some of the place-based contours of energy security through a discussion of historical and contemporary energy security in the high latitude North. Alaska and the Arctic are well known to the energy security literature because of the oil and gas reserves in 
the region, but relatively few academic studies to our knowledge have been published that evaluate the energy security of communities in the North. Studies we are aware of for Alaska are government publications and assessment reports for non-governmental organizations [xiv, $x v, x v i, x v i i, x v i i i]$. The North, while unique, is an exemplar of remote rural issues elsewhere in the world: complicated and unreliable supply chains, limited employment and economic development, a history of boom and bust economic development, and rapidly shifting demographics. Alaska is also rich in colonial legacies influencing the local energy discourse directly undermining indigenous practices, which is explored in this paper. In terms of infrastructure, the North shares a number of features with other rural and developing parts of the world, specifically distributed power generation (usually diesel) and the unfeasibility of extending electrical grids [xix, xx, xxi]. Therefore the discussion in this paper has applicability to a wider context than the case study used for illustrating purposes, for example the challenges to energy security that Alaska faces are not unknown to countries in Africa and in South Asia [xx, xxi, xxii].

We propose and justify both a definition and framework for energy security that attends to these complex circumstances at the local level. We draw guidance from the food security literature, which as noted has undergone a similar "scaling down" in focus in the last few decades from global and state-level issues to those facing individuals, households, and communities. To illustrate the usefulness of this conceptual framework, we discuss the historical timeline of heat efficiency of homes and food production in rural Alaska and the effect this has had on energy security. We believe there is value in exploring the linkage between the role historical behavior plays in present day energy use and attitudes and how this relates to energy security. We also examine contemporary issues of energy, transportation and food security and how they relate to each other directly affecting the vulnerability and resilience of communities of the region.

While some examples given in this paper refer to specific forms of energy, such as electricity, it should be clarified that the paper as a whole, including the energy security definition, is concerned with household energy use in a broad sense, including electricity, heat, and transportation.

\section{Conceptual Background}

The concept of energy security can be interpreted in a wide variety of ways based on the level and scale of interest, as well as the cultural context, which involves expectations regarding energy availability and also ethics regarding how energy ought best be generated and provisioned. 'Energy generation' as used in this paper describes technologies that convert energy resources into a form useful for human activities. At a national level, energy security is often linked to economic policies, foreign relations, financial affordability and even environmental policies [vi, vii]. From the perspective of Saudi Arabia, for example, energy security can be construed as securing global demand for their oil and gas resources; conversely in the US, energy security has come to mean securing the supply of oil at low prices, at a predictable and sustainable rate and, increasingly, from national rather than foreign sources [iv]. Similarly, for transnational oil and gas producers, energy security is linked to securing access to new reserves and widening the distribution or consumer network, giving them control of the pipeline infrastructure and access to the consumers. Whereas for consumers it likely involves both access to energy supply without disruption and affordability on a reasonable household budget. 
On a local level, people's concerns about their energy reliability and affordability also feed into concerns about societal and ecological trade-offs related to electrical power generation and other aspects of their environmental security. For example, local air quality can be severely impacted by emissions from power plants [xxiii], and household air quality can be compromised where people rely on fuel lamps for lighting [ $\mathrm{x}$ ]. Some have proposed biofuels as an alternative to carbon-based energy generation, but biofuel production can usurp land that would otherwise be used to produce food crops. Similarly, some consider hydroelectric energy to be an environmentally friendly form of energy generation, but hydroelectric dams can interfere with fisheries that are important to local food security [xxiv]. Dams can also alter downstream hydrology and affect the flow of tributaries and floodplains [xxv].

These examples illustrate the many ways that energy security interlinks in a 'nexus' with food security, water security, and environmental health [i, iii, xxvi]. This nexus approach is relatively new to the research and development literatures, and is arguably useful because it highlights linkages and potential trade-offs or synergies among these domains.

\section{Energy Security Definition and Framework}

Energy security is purported as a concept hard to define especially in a global context [xxvii, xxviii, vi, xxix]. Energy supply and demand varies largely based on the size of a country or community, the available local resources, economic development and geopolitical factors and jurisdiction, to name a few [30,31]. What energy security may encompass for a developed country in Europe with a northern temperate climate may not apply to a developing country in Africa with a warm desert climate. The heating needs, fuel resources, economic development, population size and geopolitical factors would likely all be different. One other noteworthy challenge in defining energy security is that developed countries' definition of energy security may not work well for rural communities, in that the latter may have a standard of living closer to a developing country, as our case study of rural Alaska exemplifies. As Martchamadol's [xxx] research states developed countries' understanding of energy security is often "a resilient energy system and securing the amount of energy required for people's lives, economic and social activities, defense and other purposes for acceptable prices." Developing countries, by comparison, have a differing understanding; "enough energy supply (quantity and quality) to meet all requirements at all time of all citizens at an affordable and stable price, and it also leads to sustain economic performance and poverty alleviation, better quality of life without harming the environment." Furthermore, the energy security literature often focuses on indicators of energy security in a nationalistic sense [ii,vi, xxxi, xxxii, xxxiii] that may not be appropriate for a local community.

We define energy security as a situation in which people have reliable access to socially acceptable energy generation or provisioning services, at a level sufficient to conducting a sustainable life. This definition is adapted from contemporary definitions for food security [xxxiv], with our goal being to "downscale" the energy security discussion to the household and community level in order to capture the varied and often inequitable experiences that local households and communities can have with energy [xi].

While not explicitly mentioned in our definition, it is important to clarify that energy efficiency is implied by the definition as a possible means to help achieve energy security. While energy efficiency doesn't directly affect the access to energy generation or provisioning services, it does decrease the amount of energy considered sufficient to conduct a sustainable life. As a result, there are two basic ways to increase energy security: a) increase reliable access to 
socially-acceptable energy generation or provisioning services; or b) use energy efficiency measures to decrease the amount of energy needed to conduct a sustainable life.

\subsection{A Framework for Energy Security}

Hughes [xxvii] distills three indicators from the Information Energy Agency's definition of energy security; affordability, availability and acceptability. Similarly, Giampetro and colleagues [xxvi] discuss issues of availability, viability, and desirability as being central to energy security. Here, we follow Loring and colleagues, who synthesize literature across the domains of food, water, and energy, and argue for four main components (see Figure 1) of energy security:

1. Availability on a local level, which may relate to whether communities are located in grid service areas or if there is sufficient grid infrastructure

2. Access, which involves equitable access to energy by all members of a society; this relates to the economic cost of purchasing energy as well as if individual households have connection to a utility grid

3. Utility, which involves the reliability, efficiency, and social acceptability of energy harvesting, distribution, and utilization

4. Stability, which refers to the sustainability of energy sourcing and generation, policies that regulate extraction, environmental laws and policies, local governance and the direct environmental impacts, such as bad air quality.

There are a number of ways that the four components interact with each other, in some cases creating feedback loops. Limited energy generation in an area can increase the price of energy, thus limiting equitable access to it from all community members. Similarly, drivers that affect the stability of energy sourcing will interact with access, but will also affect the availability of energy sources: while energy resources may be available, such as oil, policies and laws prohibiting its extraction will impact the utilization of the energy source. Or, if there is limited support of the use of renewable energy by existing utility companies, this can affect the access to using this energy source by driving up cost. In turn this may diminish the social acceptability of using renewable energy sources thus erecting social and economic barriers to connecting renewable energy to the utility grid. Additionally, if extracting an energy resource, such as tar sands, has environmental concerns, the utility or social acceptability of using the energy source may be affected. Adding some of the feedbacks together can also produce cumulative effects, in addition to individual interactions, locking communities into fewer options or a trajectory of energy development that they do not support [viii]. 
Figure 1. Components of Energy Security

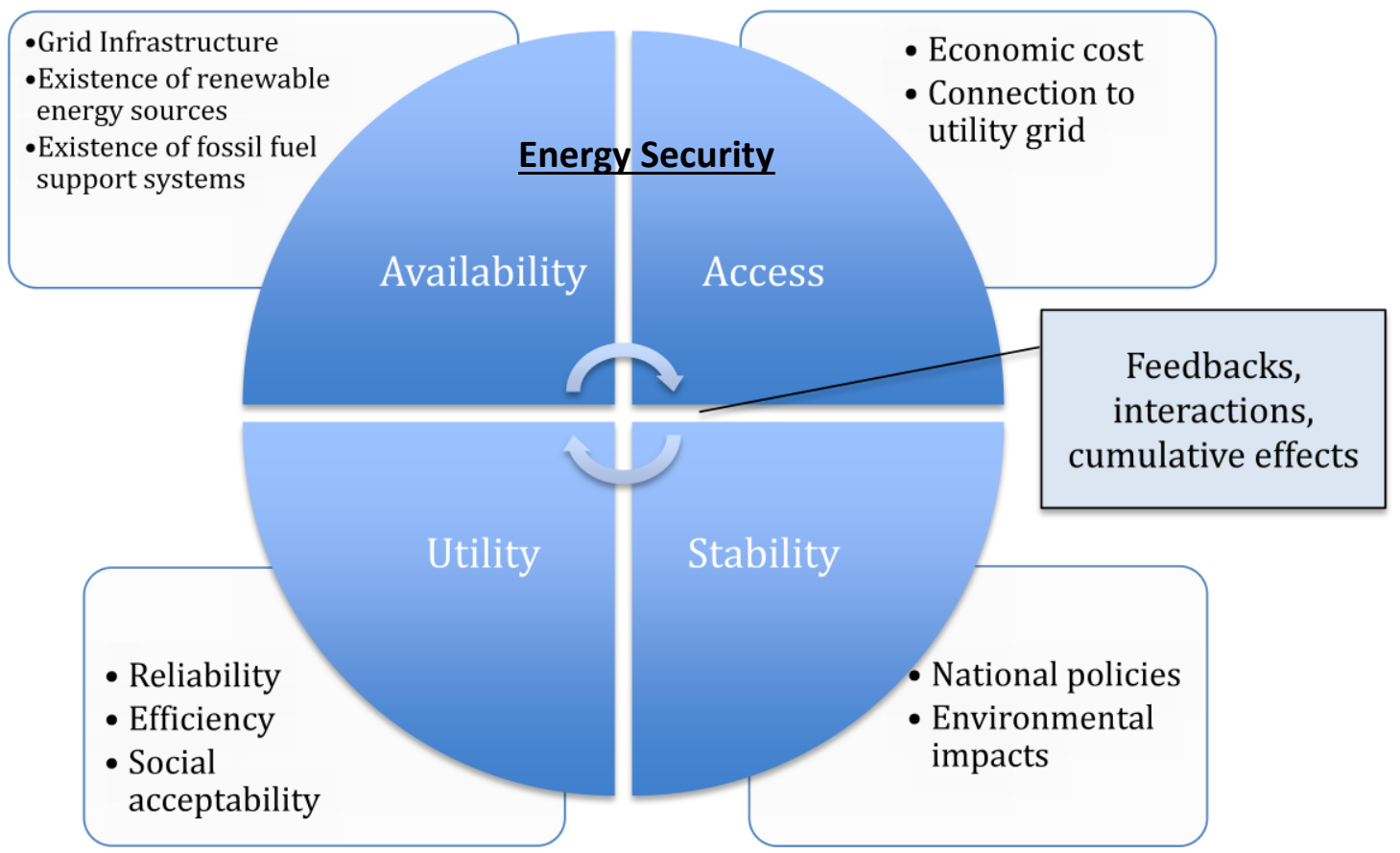

Availability, accessibility, utility and stability are used throughout this paper as shorthand for understanding the facets of energy security in Alaska at a household and community scale. In addition, we note four categories of energy use for which these four components should be evaluated in order to assess energy security (adapted from Reddy and Subramanian 1979 [xix]):

1. Food production and harvest involves the energy needs of agriculture (fuel or animal traction) or of hunting, gathering, herding, etc., including transportation

2. Household activities including cooking, heating, lighting, and personal transportation

3. Municipal activities, where relevant, include energy needs for water treatment and distribution and other public services, and lighting and heating of public spaces

4. Manufacturing and commerce, where relevant, which can have energy needs at a scale different than the previous three.

\section{Energy Security in the Pre-contact North}

Prior to Euroamerican contact, indigenous Alaskans utilized locally sourced energy sources such as seal oil and firewood, had limited energy needs and relied highly on heat-efficient housing to keep fuel requirements low. This changed with the advent of colonialization, which is elaborated on below. Of the four categories of energy use proposed above, only two (food production and household activities) are relevant in a pre-contact setting.

Differences in cultural adaptations for energy use are found throughout Alaska, in a distribution that not surprisingly coincides with the different climatic regions of the state (see also Moran 1981 [xxxv]). Energy adaptations in the Arctic, Interior, Southwest, and Aleutian 
regions of the state are all expanded upon below. A recurring observation is how these energy adaptations are interwoven with climate and biogeography and also patterns of subsistence and mobility.

The climate in Alaska is influenced largely by the high latitude environment [xxxvi]. The northern half of the state experiences limited daylight hours in the winter months and almost constant daylight during the summer. Mean temperatures have a relatively large range in the state; from $4 \mathrm{C}$ in a southern maritime region to $-12 \mathrm{C}$ north of the Arctic circle [xxxvii].

\subsection{Homes and Households}

The Iñupiat Eskimo tribes inhabiting the Northern region of mainland Alaska typically inhabited insulated sod dwellings in the winter and movable homes in the summer with a tent like structure and caribou hides [xxxviii, xxxix, xl, xli, xlii]. The winter homes were dug into the sides of sand dunes, hills or river embankments to maximize natural insulation features in the landscape. The sod insulation layers were up to one meter thick. Homes were heated primarily with sea mammal oil lamps and body heat from the inhabitants. Up to 15 people would occupy the winter homes, comprised of multiple families, constituting an occupancy rate of 1.1 to 1.7 square meters per person [xliii, xliv]. Summer tents were usually occupied by only one family, allowing for more space per person at 2.6 square meters per person. As a comparison, in 2005 the average occupancy space in the US was 57.5 square meters per person [xlv].

Energy use in winter was kept at a minimum with design features of the dwellings. For example, the entrance to the main living area was dug into the ground with a long tunnel of 3 to 9 meters in length serving as a cold air trap [xxxviii, xxxix, xl, xli, xlii]. Meat and other perishable foods were stored in this tunnel, utilizing the natural refrigeration of the winter air and the permafrost walls. Nooks in the tunnel closest to the tunnel entrance were carved into the permafrost for further storage. These combined techniques kept the indoor room temperature between 10-15 degrees Celsius during the coldest winter temperatures, which often reached $51 \mathrm{C}$, roughly a difference of $60 \mathrm{C}$ between the outdoor and indoor temperatures achieved without the use of burning wood or oil. Energy security for the Iñupiat Eskimo was therefore closely linked to successful seal hunts, having large families and the ability to build wellinsulated sod homes.

In the interior of Alaska, by comparison, Athabascan people were historically highly mobile, moving from camp to camp with the hunting and fishing seasons. In summers they built tent dwellings similar to the tents used by the Eskimos in the North of Alaska [xlvi, xlvii]. Some families chose to live in the tents year-round and added an extra layer of animal hide to the walls of the tent with the fur attached on the inside to act as additional insulation. Some also used semi-permanent winter homes, though this varied slightly across the interior region based on differences in climate and natural resources. Most commonly, such structures were similar to the sod homes described above, built semi-subterranean with wood framing covered with spruce or birch bark and a layer of soil for extra insulation as well as moss. Other versions included wood boards covered with woven grass on the outside. When it snowed, the snow blanket functioned as additional insulation over the dwellings. Wood, as well as animal oil fires were built for cooking and heating. Wood and cooking oil were readily available and the small scale of burning wood did not lead to unmanageable air pollution. Energy conservation, in the form of multifamily dwellings and shared cooking were also practiced. It is noteworthy however that while there is no evidence that outdoor air quality was poor as a result of these fuel uses, indoor air quality problems from lamp smoke has been identified as a likely cause for emphysema among some pre-contact northern peoples [xlviii]. 
The Yup'ik of Southwest Alaska also occupied similar sod homes year-round [xl, xliv, xlix]. Milder temperatures than in the Interior allowed for the homes to be built above ground in many cases. Entrance tunnels, while shorter than in Iñupiat homes, were still used as a cold air trap. Some homes had two entrances: one tunnel below ground as the winter entrance and one above ground as the summer entrance. In some instances, the only heat source in the sod homes was that generated by the bodies of the residents. This was mainly possible in homes where interior square meter-to-inhabitant ratio was relatively small, on average 0.8 square meters per person, and for homes with sufficient insulation [xliii, xliv, I]. Other heat sources came from lamps and fires.

Aleut and Alutiiq people in the Alaska Peninsula and Aleutian Islands region lived typically in multifamily dwellings that were made out of primarily grass and turf layers coated on the outside with mud, earth, clay or bark. These homes were called barabaras by early Russian settlers, a name later adopted as the common term for this type of house [xliii, xliv, li]. Heating and light was provided with sea mammal oil lamps and cooking was done over a fireplace also fueled by sea mammal oil. Some homes included stone foundations and had stone slab hearths with stone channels capable of funneling heat and steam through the floor to create an efficient form of floor heating [xliii, lii]. These homes provided 1.9-2.8 square meters of living space per person [xliii, xliv].

\subsection{Food Systems Linkages}

Historically, Alaska Native food systems provided people with a high measure of food security through adaptive strategies tailored around high levels of seasonal variability, mobility, and innovation [61]. These food systems activities have also been particularly energy efficient, relying primarily on human energy (labor) and innovative methods of food storage.

Transportation was key, given the emphasis on hunting, fishing, and gathering of diverse botanical resources; Athabascan people relied heavily on dog teams for hauling wood and other supplies and for transportation to winter hunting grounds; Aleut people similarly traveled the coastal environment extensively with kayaks, and Yupik and Iñupiat whalers navigated the icefilled waters of the Arctic Ocean with the impressive, hand-made umiaq skin boats.

Energy use for food storage was kept relatively low. As mentioned above, during the cold months ice, snow or permafrost was used as natural refrigeration in cellars and nooks. In warmer months, foods were mostly eaten fresh, fermented, dried or smoked, requiring at most small wood fires.

\subsection{Colonial Changes}

Alaska Natives transitioned to living year-round in fixed villages primarily as a result of government policies requiring that their children attend school [liii]. The social impacts of the transition have been noteworthy and lasting: food security was impacted because living in fixed villages reduces people's ability to move across the landscape [lxii]; water security and sanitation emerged as problems [liv], and as we discuss here, energy security was impacted in myriad ways.

Wood frame houses, for example, arrived with the first Euroamerican settlers in the Arctic region near Barrow over one hundred years ago. These houses were drafty and not well insulated by comparison to traditional structures, and as such they required large amounts of fuel for heating [xxxviii, lv]. The advent of the sheet iron stove, using wood as a fuel source, also drastically changed home heating practices in the North [lv], because it generated a substantially larger amount of heat compared to the sea mammal oil lamps and was also lightweight and portable. Arguably, the shortening of tunnel length and elimination of the cold 
trap and the subterranean characteristic of the Eskimo sod houses that has been observed in the historical archaeological record can be attributed to the introduction of colonial housing elements, such as the new wood stove, above ground housing with windows and larger area per occupant [lvi]. However, since trees in Alaska's Arctic North were not abundant and driftwood was of short supply, lumber to build the new wood frame houses and to fuel sheet iron stoves was scarce. Residents were thus forced to use imported lumber for construction and later imported coal and wood to fuel the sheet iron stoves for heat.

In Southwest Alaska, the Russian settlers brought with them a change in architecture as well. The first features adopted were Western-style doors and windows for the barabaras made out of imported wood from Siberia or Europe [xliii]. Gradually throughout Alaska, homes were built above ground and included more and more timber and less of the locally available turf and sod. Overall the house design the settlers introduced to Alaska was better suited for a European climate and fuel source availability.

The US Government pressured Alaska Natives to leave their traditional homes as early as the 1800 s offering financial help [Ivii] though the promises for assistance for these "development" initiatives were often not realized [lviii, lix]. Aid that did come was used to build homes that were often substandard, not meeting the requirements of the local climate or the culture of the inhabitants. In the mid $20^{\text {th }}$ century the Bureau of Indian Affairs and the Department of Housing and Urban Development funded a massive housing boom for all Indigenous tribes throughout the US [Iviii]. The homes were all modeled after post-World War II tract housing, in an attempt to help Indigenous people assimilate into the prevailing culture. These types of homes were clearly not suitable for the Alaskan climate, built to federal codes rather than local construction standards. The homes were similar to the new home designs the settlers introduced. In addition to inadequate insulation and imported building materials, heating appliances were generally powered by fuel oil, which also had to be imported. Additionally, many of these homes did not have adequate ventilation, which created mold problems and impacted the respiratory health of residents [Iviii].

The legacy of the homes built by the federal government is still visible in Alaska today. In 2005 , a study found that over $21 \%$ of households in Alaska were unable to maintain an indoor temperature of 21 degrees Celsius, both due to the high cost of heating fuel as well as inadequate construction or condition of the house [Ix]. Out of this subsection, $45 \%$ had a household income of $\$ 30,000$ or less, indicating that affordability of fuel oil is an important driver. For nine percent of homes surveyed, however, the single biggest problem for effective heating was found to be the condition of the house.

\section{Contemporary Energy Security Concerns in Alaska}

In rural Alaska, dependence on fossil fuel permeates all of the categories of energy use noted above: subsistence and food production, household activities, municipal activities, and industry. Today, imported diesel and gasoline are the primary energy sources for rural Alaskan villages [lxi]. Diesel is used for electricity and heat for household, municipal and industrial activities, and gasoline is used as fuel for snowmobiles and four-wheelers for subsistence activities as well as transport of imported goods, including food and supplies from hub communities. Energy and other municipal infrastructure in rural Alaska is also relatively new, designed when fossil fuel was inexpensive, abundant, and not implicated in climate change. Indeed, Alaskans now are locked in to an overreliance on imported fuel for all aspects of rural life, which makes them vulnerable to any environmental, economic or social change that affects the supply or price of fuel [lxii]. 
Rural communities have a unique challenge in that a large number of rural areas are accessible only by plane or barge as they are not on the road system. This increases the general cost of living when compared to the urban centers [Ixiii] because the majority of goods, including fuel, building supplies, and food has to be imported long distances. Likewise, the cost of energy in rural regions can be as high as $\$ 10 /$ gallon of diesel and over $\$ 1 / \mathrm{kWh}$ for electricity [lxiv, Ixv]. Colt et al [lxvi] estimate that the consumption of diesel fuel and gasoline in rural Alaska equals roughly 1,000 gallons per person annually, including fuel consumption for heating, electricity and transportation, but not including the indirect fuel costs associated with imported foods. Electric utilities in rural areas receive high subsidies from the state, such as through the Power Cost Equalization Program, to be able to lessen the cost of energy such that local utilities can be sustainable [lxvii]. Nevertheless, even temporary fluctuations in the cost of fuel can drive local families into an energy insecure state [Ixiii].

Fossil fuel use in rural Alaska also has impacts on local ecosystems. For example, storage of diesel is key because fuel can only be barged to many communities in the summer months because of river and sea ice (most rural communities in Alaska are not on the road system). Due to aging and inadequate infrastructure, storing a year's worth of diesel and gasoline can lead to leaking storage tanks, spills and discarded drums that all have adverse impacts on the ecosystem and human health [Ixviii]. Chapman [Ixviii] estimated the cost of remediating the environmental impacts caused by emissions and spills from diesel engine operation at an additional \$3/gallon.

Finally, the community power plant equipment is likewise often at risk of failing, leaving entire communities without power for weeks. Maintenance and repair is difficult in remote communities that are not accessible by road and often don't have skilled technicians living in the community. Moreover, in the event of a disaster or other shutdown of all transportation modes to Alaska the import of fuel would cease and the overall livability of remote communities would be considerably impacted. This scenario happened in a community in Northwest Alaska in the fall of 2011. The annual fuel delivery by barge to Nome could not occur due to a severe storm in the Bering Sea making the water impossible to navigate [Ixix]. By the time the storm died down Nome was already locked in by sea ice. The residents did not have enough fuel to last through the winter. With no other way to get enough fuel for the entire town a Russian ice breaker had to make the trip to transport the fuel to Nome. Flying the fuel in by plane would have raised the fuel prices from $\$ 5.40$ to $\$ 9$ per gallon and as such been cost prohibitive for the residents [lxx]. The emergency fuel did not reach the community until January 2012 [Ixxi].

\subsection{Food-Energy Interactions}

Alaska's rural community food systems, including both subsistence and small-scale agricultural production, are also now much more energy dependent than they were in the past, with transportation as one example. The predominantly subsistence lifestyle requires fuel for hunting and fishing with snowmobiles, all terrain vehicles, and motorboats. Climate change is also affecting the subsistence lifestyle of many rural Alaskans [lxii]: retreating sea-ice, shorter freeze periods of rivers and lakes and changing vegetation patterns leading to changing game migration patterns are impacting the availability of fish and game and safety of transportation across land, rivers, and the ocean. Due to these factors, as well as the creation of federal and state parks, restricted hunting and fishing on private land and the high cost of fuel, the reliance on subsistence foods in rural Alaska is continuously decreasing [Ixxii]. With reduced access to and availability of subsistence foods, community members rely on larger amounts of imported foods. On average food sold in local grocery stores travels a long distance from the lower 48 before reaching Alaska and as such the price of food and fuel in these communities is tightly coupled (Figure 2), with the cost of the foods sold in the village stores is as much as 2-5 times 
that of food sold in the contiguous U.S. [Ixii].

Figure 2. Comparisons of food and gasoline prices/gallon (2013 USD) for Portland, OR, Fairbanks, AK, and Bethel, AK. Note the spike in costs during the 2008 fuel crisis.

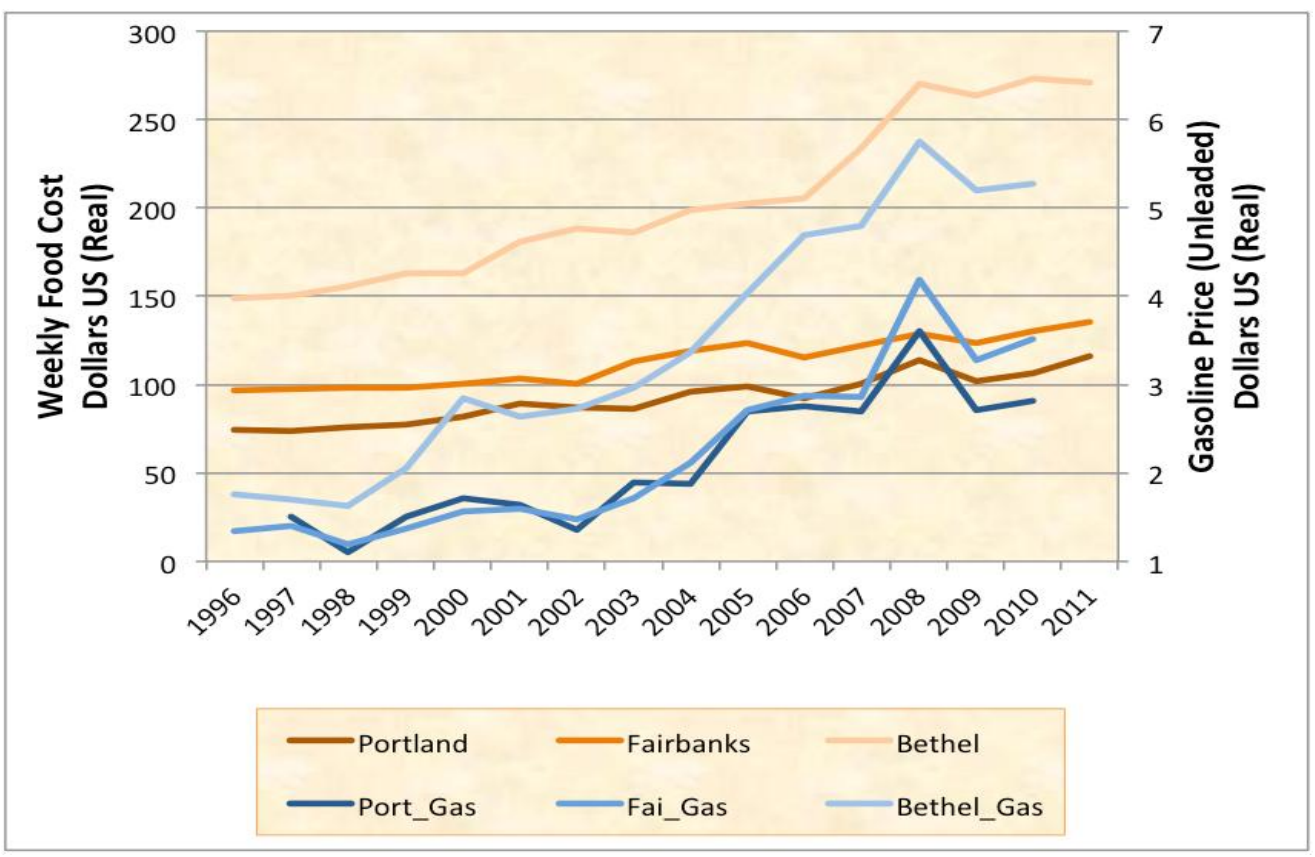

\subsection{Household and Municipal Uses}

Energy for heat, lighting and running electric appliances is important to both household and municipal buildings. Families often feel energy insecure if they cannot afford the high cost of electricity and heating fuel to be comfortable throughout all of the seasons of the year. With the upkeep of a modern lifestyle that includes using electronics such as TV, computer, mobile devices and game consoles electricity use is furthermore increased. Municipal energy use has similar concerns, such as being able to keep offices heated adequately and have enough budgeted to pay for electricity without needing to cut-back on other areas. Aside from the availability factor of fuel in rural Alaska, increasing fuel prices coupled with the high cost of food are leading some low-income families to decide whether to spend a large portion of their income on either food or fuel to heat their home because they can't afford both [lxiii, Ixxiii]. Rural low-income families spent up to $47 \%$ of their household income on home energy use in 2008 , as compared to urban families who spent up to $18 \%$ [lxxiv].

\subsection{Stability}

One way to evaluate the question of whether or not the existing energy economy in rural Alaska can be maintained over time is with the concepts of resilience and vulnerability. When energy security is viewed through the lens of resilience it can be interpreted as energy selfreliance and independence. Resilience in this context is the magnitude of a change in supply and demand, delivery or affordability of energy services that the system could withstand without experiencing a fundamental change in the energy security baseline [ $\mid x x v$, Ixxvi]. For example, the resilience of a household is determined by how long they can continue generating 
and using power if an ice storm prevents shipment of fuel to their region if their sole power source is imported fuel. Increased resilience can take the shape of additional fuel drums that a household has in storage but could also be their ability to adapt, reorganize and innovate. One example is if households join forces and share cooking and other electrical needs they can stretch their combined fuel reserves, thus increasing their resilience to the system shock.

An increased dependence on imported food also increases the reliance on fuel for the transportation of the food to the store and the electricity to power the freezers, fridges and lights in the store. An example of a situation where aging infrastructure in a local community power plant failed and affected food security occurred in the fall of 2014 in the village of Tuluksak, near Bethel in Southwest Alaska. All three generators in the local power plant failed at the same time, leaving the village with no power [lxxvii, Ixxviii]. The main concern was keeping the villages' food supply in freezers from thawing. Many families store the bulk of the food they consume throughout the winter in freezers. The school and the village store have private generators and can remain open, however the village clinic did not have any power. None of the generators were salvageable and new generators are very costly. The state of Alaska flew in an emergency generator to turn the power back on in the village, but the residents were without power for over two weeks.

In January 2016 another village in Alaska was left without power for four days [lxxix]. The only generator in Newtok, a rural community in Southwest Alaska, failed leaving the entire community without power. The main concern for residents was keeping warm. The state flew in an emergency generator. In total roughly $\$ 30,000$ was spent restoring power to the community. This scenario again addresses the availability component of energy security, but merely replacing the generators does not address the access, utility or stability of the future energy security of the village.

Vulnerability of rural energy security increases if there is a sole reliance on imported energy sources, such as oil and gas. If there are diversified energy sources combined with energy conservation measures the resilience is increased multifold. In parallel with issues surrounding food security, availability of raw materials for generating energy is often not the culprit; it is access and distribution that needs to be improved upon [lxxx]. The natural resources of Alaska provide a host of energy options: aside from oil there is solar, wind, hydro, geothermal, biomass, tidal and natural gas, but access to technology to harness and use these for generation is limited and slow to progress [lxxxi]. Potentially due to its nature as an oil and gas supplying region, coupled with the legacy of climate inappropriate home heating and construction models the vast majority of households are largely dependent on oil and gas in the rural areas. Affordability often rules out exploring alternative energy sources on a household level, though a number of organizations and state programs are on the upswing to provide assistance in the adoption of renewable energy and climate appropriate house designs [Ixxxii, Ixxxiii].

\section{Discussion}

The contrast of historical and contemporary energy uses and needs in rural Alaska illustrates the importance of adopting a place-based approach to energy security. While the state itself is a major oil producer and urban households are all connected to energy grids, the picture in rural Alaska is one of vulnerability more than resilience, a result of expensive imported fuel with unreliable import schedules, inefficient homes and inefficient use of heating fuel. A significant segment of the population is therefore energy insecure, specifically within three out of the four energy use categories proposed above. Food systems, household activities, and municipal activities -- such as water supply and heated public buildings -- are all vulnerable. 
The categories of access, availability, utility, and stability add clarity to our assessment. There are abundant energy resources available in Alaska including oil, natural gas, geothermal, solar, wind, biomass, hydro and ocean/tidal power [lxxxiv] but most people do not have widespread access to these options. While some subsidies exist, they are often not sufficiently high to make these options affordable. Since the current predominant fuel type in remote Alaskan communities is diesel, increasing access in the current system would mean purchasing and storing additional drums for fuel or facilitating cheaper fuel transportation to rural communities on a more frequent schedule. This however, can affect stability through the environmental impact, since this increases the risk for leaking fuel drums causing polluted ground and water resources. It would simultaneously impact the affordability of energy as more upfront payment would be needed to purchase the fuel drums. Branching out into renewable energy sources, such as wind, solar and hydropower would afford a larger availability of energy. However, installing renewable energy in rural Alaska can also be cost prohibitive because of the high costs of shipping the equipment. A number of non-profit organizations and state funded grants are providing assistance in installing wind turbines and tapping into geothermal power, as well as utilizing solar energy for community buildings, to heat greenhouses and provide hot water [lxxxv]. This is in alignment with Alaska's energy policy to obtain half of the state's electricity from renewable sources by 2025 [Ixxxvi].

As stated earlier, energy costs in rural Alaska are relatively high compared to urban areas in the state. Rural inhabitants therefore are often confronted with trade-offs, in some cases choosing between heating or eating. This raises the important question of how much energy is required to maintain a sustainable standard of living. While that amount can vary from household to household, we believe that most would agree that having to choose between food and heating a home is not consistent with any possible definition of energy security.

The utility dimension of energy security encompasses both the energy efficiency of the technologies at use as well as the social and cultural acceptability and appropriateness of those technologies. Historically, technologies used in rural Alaska for housing, hunting, even clothing embedded aspects of energy security; today, we argue that new energy options would likewise need to be place-based, that is, designed according to locally available energy sources and governed locally. The efficiency of technologies used for the four activities above play an important role as well, whether for buildings, appliances, transport vehicles or machinery. Energy efficiency is supported by Alaska's energy policy to decrease energy use per capita by 15 percent by 2020 [lxxxvi]. If homes are heat efficient, less of the heating fuel will be required, thus lowering the yearly cost, thus increasing affordability, which allows for less trade-offs and arguably can increase the standard of living if tradeoffs between using fuel and purchasing household goods or food does not need to be factored in any longer. Education to increase the energy literacy of homeowners is also an important part of the solution, especially when it comes to simple measures such as replacing light bulbs for more efficient ones [lxxxvii]. Energy literacy also gives homeowners more control over their energy security.

It is important that an indigenous and decolonized conversation be had about energy security in the North and how it ought to be pursued, with some skepticism at least about whether new technologies developed outside the North make sense for northern people and places. As elaborated above, colonialism of Alaska and the invasion of settlers significantly changed the fuel sources, energy uses and home energy efficiency of the indigenous populations. Households went from using appropriate, locally available, affordable and very efficient methods of using energy sources with a relatively fuel secure situation to a complete conversion using imported fuel sources. Additionally, the imported fuel was used at a much higher rate due to energy inefficient homes, which impacted affordability of energy directly 
leading to a questionable if not energy insecure situation for most households. The colonial legacy cannot be underestimated when reviewing the energy situation of a region. As can be seen with organizations building homes with features of pre-contact homes, sometimes the way forward to increase energy security is to take a look backwards.

Finally, and as noted above, rural energy systems are lacking stability, both in terms of the vulnerabilities that communities are exposed to through current systems and also because of the inherent unsustainability of those technologies. The carbon pollution associated with oil and gas extraction, transportation and burning fossil fuels for its end-use is well known, and the climatic changes that are resulting are impacting livelihoods in rural Alaska in myriads of ways. With the effects of climate change already visible, the local environmental consequences of fossil fuel-based energy generation multiply the problems. However, due to limited availability and access to alternatives, residents don't usually have a choice in the matter. Implementing energy efficiency measures is one possible exception. Though there is typically an upfront cost associated with energy efficiency improvements and the payback rate is low, especially when oil prices in rural Alaska are relatively high.

\section{Conclusion}

Whether the place is rural Africa or rural Alaska, the primary drivers and determinants of energy security at the household level will invariably involve some combination of historical, economic, political, geological, cultural and ecological dimensions. As has been previously done for food security, we offer here a framework for "downscaling" the energy security discussion to bring clarity to these dimensions and how they interact. In so doing, we have illustrated the highly place-based nature of energy security and how it interacts with other components of the food-water-energy nexus. If energy democracy and/or energy justice are the goals, it is imperative that policies take these localized contours into account.

Alaska is fruitful with oil and gas reserves (which benefit the state's treasury) but its people are lacking in rural energy security. In this Alaska is similar to many other oil producing nations that lack the infrastructure, policies, or political will to ensure that outcomes are equitable and their people are secure. Many government and non-governmental organizations in Alaska are working with remote communities to lessen their overreliance on imported fuel through renewable energy generation, though the costs remain high and institutional support is only nascent. What we learn from the discussion above is that building energy security in these places is not just a matter of implementing the latest and greatest alternative energy technologies, but also of confronting the structural and built legacies of colonialism. To that end, it is essential that local governance and decisions regarding the cultural appropriateness of technologies must play a central role in shaping a region's energy future. Planners and policymakers must look at the local discourses surrounding alternative energy when developing these solutions such that local people are literally and figuratively empowered by reforms; the alternative is to repeat past mistakes by implementing technologies that do not meet local needs and that lock people into a posture of dependency.

\section{Acknowledgements}

This research is a part of the Sustainable Futures North program, funded by a grant from the US National Science Foundation (Grant \#1263853) and also a grant from the US Department of Agriculture (2013-70003-2092). This research was also supported in part by a UAF Center for Global Change Student Research Grant with funds from the UAF Center for Global Change and 
based upon work supported by the National Science Foundation under Grant Number 1146538 and the National Institute of Food and Agriculture, U.S. Department of Agriculture, under Award No. 2014-02378.

\section{References}

[1] Loring, P. A., Gerlach, S. Craig, \& Huntington, H. P. (2013). The New Environmental Security: Linking Food, Water and Energy for Integrative and Diagnostic Social-Ecological Research. Journal of Agriculture, Food Systems and Community Development, Advance online publication. doi: 10.5304/jafscd.2013.034.005

[2] Sovacool, Benjamin K., \& Mukherjee, Ishani. (2011). Conceptualizing and measuring energy security: A synthesized approach. Energy, 36(8), 5343-5355. doi: 10.1016/j.energy.2011.06.043

[3] Bizikova, Livia, Roy, Dimple, Swanson, Darren, Venema, Henry David, \& McCandless, Matthew. (2013). The water-energy-food security nexus: Towards a practical planning and decision-support framework for landscape investment and risk management: International Institute for Sustainable Development.

[4] Sovacool, Benjamin K., \& Brown, Marilyn A. (2010). Competing Dimensions of Energy Security: An International Perspective. Annual Review of Environment and Resources, 35, 77-108. doi: 10.1146/annurev-environ-042509-143035

[5] Bielecki, J. (2002). Energy Security: Is the Wolf at the Door? The Quarterly Review of Economics and Finance, 42(2), 235-250. doi: 10.1016/S1062-9769(02)00137-0

[6] Kruyt, Bert, van Vuuren, D.P., de Vries, H.J.M., \& Groenenberg, H. (2009). Indicators for Energy Security. Energy Policy, 37(6), 2166-2181. doi: 10.1016/j.enpol.2009.02.006

[7] Yergin, Daniel. (2006). Ensuring energy security. Foreign Affairs - New York, 85(2), 69.

[8] Unruh, Gregory C. (2000). Understanding carbon lock-in. Energy Policy, 28(12), 817-830. doi: 10.1016/S0301-4215(00)00070-7

[9] Bottomly, J.M. (2001). Energy Assistance Programs: Keeping Older Adults Housed and Warm. Topics in Geriatric Rehabilitation, 17, 71-81.

[10]Mills, E. (2005). The Specter of Fuel-based Lighting. Science (Washington), 308, 12631264.

[11]Maxwell, Simon. (1996). Food security: a post-modern perspective. Food Policy, 21(2), 155-170. doi: 10.1016/0306-9192(95)00074-7

[12]Maxwell, Simon, \& Smith, Marisol. (1992). Household food security: a conceptual review. Household Food Security: concepts, indicators, measurements. Edited by S. Maxwell and T. Frankenberger. Rome and New York: IFAD and UNICEF.

[13]Loring, P. A., \& Gerlach, S. Craig. (In Press). Searching for Progress on Food Security in the North American North: A Research Synthesis and Meta-analysis of the Peer-review Literature. Arctic.

[14]Colt, S., Goldsmith, S., Wiita, A., \& Foster, M. (2003). Sustainable Utilities in Rural Alaska: Final report. Prepared for USDA Rural Development and Alaska Science and Technology Foundation.

[15]Martin, Stephanie, Killorin, Mary, \& Colt, Steve. (2008). Fuel Costs, Migration, and Community Viability. Denali, Alaska: Institute of Social and Economic Research in collaboration with First Alaskan Institute and Alaska Native Policy Center. 
[16]Wilson, Meghan, Saylor, Ben, Szymoniak, Nick, Colt, Steve, \& Fay, Ginny. (2008). Components of Delivered Fuel Prices in Alaska. Anchorage, AK: University of Alaska Anchorage Institute of Social and Economic Research.

[17]Fresco, Nancy, \& III, F. Stuart Chapin. (2009). Assessing the Potential for Conversion to Biomass Fuels in Interior Alaska. (Res Pap. PNW-RP-579). Portland, OR.

[18]Nicholls, David. (2009). Wood Energy in Alaska - Case Study Evaluations of Selected Facilities. (Gen. Tech. Rep. PNW-GTR-793). Portland, OR.

[19]Reddy, Amulya Kumar N, \& Subramanian, DK. (1979). The design of rural energy centres. Paper presented at the Sadhana (Academy Proceedings in Engineering Sciences).

[20]Brew-Hammond, Abeeku, \& Kemausuor, Francis. (2009). Energy for all in Africa - to be or not to be?! Current Opinion in Environmental Sustainability, 1(1), 83-88. doi: http://dx.doi.org/10.1016/j.cosust.2009.07.014

[21] Hiremath, R. B., Kumar, B., Balachandra, P., Ravindranath, N. H., \& Raghunandan, B. N. (2009). Decentralised Renewable Energy: Scope, Relevance and Applications in the Indian Context. Energy for Sustainable Development, 13, 4-10.

[22]Amigun, B., Sigamoney, R., \& Blottnitz, H. von. (2008). Commercialisation of Biofuel Industry in Africa: A Review. Renewable and Sustainable Energy Reviews, 12, 690-711. doi: 10.1016/j.rser.2006.10.019

[23] Gaffney, Jeffrey S, \& Marley, Nancy A. (2009). The impacts of combustion emissions on air quality and climate-From coal to biofuels and beyond. Atmospheric Environment, 43(1), 23-36. doi: 10.1016/j.atmosenv.2008.09.016

[24]Brown, J. Jed, Limburg, Karin E., Waldman, John R., Stephenson, Kurt, Glenn, Edward P., Juanes, Francis, \& Jordaan, Adrian. (2013). Fish and hydropower on the U.S. Atlantic coast: failed fisheries policies from half-way technologies. Conservation Letters, 6(4), 280-286. doi: $10.1111 /$ conl.12000

[25]Poff, Leroy N., \& Hart, David D. (2002). How Dams Vary and Why It Matters for the Emerging Science of Dam Removal. BioScience, 52(8), 659-668. doi: 10.1641/0006-3568

[26] Giampietro, Mario, Aspinall, Richard J., Ramos-Martin, Jesus, \& Bukkens, Sandra G.F. (2014). Addressing the Compexity of Integrated Resource Assessment. In M. Giampietro, R. J. Aspinall, J. Ramos-Martin \& S. G. F. Bukkens (Eds.), Resource Accounting for Sustainability Assessment; The Nexus Between Energy, Food, Water and Land Use (pp. 18): Routledge.

[27] Hughes, Larry. (2012). A generic framework for the description and analysis of energy security in an energy system. Energy Policy, 42, 221-231. doi: http://dx.doi.org/10.1016/j.enpol.2011.11.079

[28]Chen, Zhan-Ming, Chang, Yuan, \& Sun, Yi-Ming. (2015). How Does Energy Security Definition Vary Across Nations? A Review of Major Energy Consumers. Journal of Technology Innovations in Renewable Energy, 4(2), 73-79. doi: http://dx.doi.org/10.6000/1929-6002.2015.04.02.4

[29]Chester, Lynne. (2010). Conceptualising energy security and making explicit its polysemic nature. Energy Policy, 38(2), 887-895. doi: http://dx.doi.org/10.1016/j.enpol.2009.10.039

[30]Martchamadol, Jutamanee, \& Kumar, S. (2013). An aggregated energy security performance indicator. Applied Energy, 103, 653-670. doi: http://dx.doi.org/10.1016/j.apenergy.2012.10.027 
[31]Löschel, Andreas, Moslener, Ulf, \& Rübbelke, Dirk T. G. (2010). Indicators of energy security in industrialised countries. Energy Policy, 38(4), 1665-1671. doi: http://dx.doi.org/10.1016/j.enpol.2009.03.061

[32] Greene, David L. (2010). Measuring energy security: Can the United States achieve oil independence? Energy Policy, 38(4), 1614-1621. doi: http://dx.doi.org/10.1016/j.enpol.2009.01.041

[33]Winzer, Christian. (2012). Conceptualizing energy security. Energy Policy, 46, 36-48. doi: http://dx.doi.org/10.1016/j.enpol.2012.02.067

[34]FAO. (2013). The State of Food Insecurity in the World 2013: The Multiple Dimensions of Food Security. Rome, Italy: Food and Agriculture Organization of the United Nations.

[35]Moran, Emilio F. (1981). Human Adaptation to Arctic Zones. Annual Review of Anthropology, 10, 1-25.

[36]The Alaska Climate Research Center. (2016). Alaska Climatology. Retrieved January 31, 2016, from http://akclimate.org/Climate

[37]Western Regional Climate Center. (2016). Climate of Alaska. Retrieved January 31, 2016, from http://www.wrcc.dri.edu/narratives/ALASKA.htm

[38]Slaughter, Dale. (1982). The Point Barrow House Type: An Analysis of Archeological Examples from Siraagruk and Other Sites in Northern Alaska. In A. D. Shinkwin (Ed.), Anthropological Papers of the University of Alaska (pp. 141-158). Fairbanks, AK.

[39]Giddings, James Louis Jr. (1952). The Arctic Woodland Culture of the Kobuk River The University Museum. Philadelphia, PA: University of Pennsylvania.

[40]Murdoch, John. (1852). Ethnological Results of the Point Barrow Expedition. In J. W. Powell (Ed.), Ninth Annual Report of the Bureau of Ethnology. Washington, DC: Smithsonian Institution.

[41]Mauss, Marcel, \& Beuchat, Henri. (1979). Seasonal Variations of the Eskimo - A Study in Social Morphology. London, UK: Routledge \& Kegan Paul Ltd.

[42]Spencer, Robert F. (1959). The North Alaskan Eskimo: A Study in Ecology and Society Bulletin 171. Washington, DC: Bureau of American Ethnology. Smithsonian Institution.

[43]Rogers, Jason S. (2012). Architecture and Complex Hearth Features at the Amaknak Bridge Site, Eastern Aleutian Islands, Alaska. Arctic Anthropology, 48(2), 92-112. doi: 10.1353/arc.2012.0004

[44]Lee, Molly, \& Reinhardt, Gregory A. (2003). Eskimo Architecture: Dwelling and Structure in the Early History Period. Fairbanks, AK: University of Alaska Press.

[45]Blake, Kevin S., Kellerson, Rebecca L., \& Simic, Aleksandra. (2007). Measuring Overcrowding in Housing. In I. International (Ed.). Fairfax, VA: U.S. Department of Housing and Urban Development - Office of Policy Development and Research.

[46]Deer, Charlie, George, Marquam, Kaluza, Phil, Loudon, Phil, Moore, Ginny, Musick, Mike, ... Woodward, John. (2008). Alaska Residential Building Manual. In R. Seifert (Ed.), (Vol. 7th Edition). Fairbanks, AK: Cooperative Extension Service, University of Alaska Fairbanks.

[47]Partnow, Patricia H. (1985). Alaska Athabascans Indian Education Act Project. Anchorage, AK.

[48]Bishop, K. (2011). Thule Palaeopathology: The health concerns of an arctic lifestyle. Totem: The University of Western Ontario Journal of Anthropology 19(1):4.

[49]Ray, Dorothy Jean, \& Edmonds, H.M.W. (1966). The Eskimo of St. Michael and Vicinity as Related by HMW Edmonds. Fairbanks, AK: University of Alaska Press. 
[50]Fienup-Riordan, Ann. (2000). Where the Echo Began and Other Oral Traditions from Southwestern Alaska Recorded by Hans Himmelheber. Fairbanks, AK: University of Alaska Press.

[51]McCartney, Allen P, \& Veltre, Douglas W. (1999). Aleutian Island prehistory: Living in insular extremes. World Archaeology, 30(3), 503-515. doi: 10.1080/00438243.1999.9980426

[52]Knecht, Richard, \& Davis, Richard. (2004). Amaknak Bridge Site Data Recovery Project Final Report \# Mgs-Stpbr-0310 (S)/52930. Anchorage, AK: Museum of the Aleutians, Unalaska and Alaska Department of Transportation.

[53]Barnhardt, Carol. (2001). A History of Schooling for Alaska Native People. Journal of American Indian Education, 40(1), 1-30.

[54]Eichelberger, Laura Palen. (2010). Living in Utility Scarcity: Energy and Water Insecurity in Northwest Alaska. American Journal of Public Health, 100(6), 1010-1018. doi: 10.2105/AJPH.2009.160846

[55]Stefansson, Vilhjalmur. (1913). My Life with the Eskimo. New York, NY: The Macmillan Company.

[56]Whitridge, Peter. (2008). Reimagining the Iglu: Modernity and the Challenge of the Eighteenth Century Labrador Inuit Winter House. Archaeologies, 4(2), 288-309. doi: 10.1007/s11759-008-9066-8

[57]Office of Indian Affairs. (1877). Annual Report of the Commissioner of Indian Affairs for the Year 1877. Washington, DC: Office of Indian Affairs.

[58]Seltenrich, Nate. (2012). Healthier Tribal Housing: Combining the Best of Old and New. Environmental Health Perspectives, 120(12), a460. doi: 10.1289/ehp.120-a460

[59]GAO. (1978). Substandard Indian Housing Increases Despite Federal Efforts - a Change Is Needed. In T. C. General (Ed.), Report to the Congress of the United States. Washington, DC: U.S. General Accounting Office.

[60]Rogers, Brian, \& Lister, Cady. (2005). 2005 Alaska Housing Assessment. In A. H. F. Corporation (Ed.). Fairbanks, AK: Information Insights prepared for Cold Climate Housing Research Center.

[61] Isherwood, William, Smith, J. Ray, Aceves, Salvador M., Berry, Gene, Clark, Woodrow, Johnson, Ronald, ... Seifert, Richard. (2000). Remote power systems with advanced storage technologies for Alaskan villages. Energy, 25(10), 1005-1020. doi: 10.1016/s0360-5442(00)00028-1

[62] Gerlach, S. Craig, Loring, Philip A., Turner, Amy, \& Atkinson, David E. (2011). Food Systems, Environmental Change, and Community Needs in Rural Alaska. In A. L. L. Hajo Eicken (Ed.), North by 2020: Perspectives on a Changing North. Fairbanks, AK: University of Alaska Press.

[63]Fazzino, David V., \& Loring, Phillip A. (2009). From Crisis to Cumulative Effects: Food Security Challenges in Alaska. NAPA Bulletin, 32, 152-177. doi: 10.1111/j.15564797.2009.01033.x

[64]Hamilton, Lawrence C., White, Daniel M., Lammers, Richard B., \& Myerchin, Greta. (2011). Population, climate, and electricity use in the Arctic integrated analysis of Alaska community data. Population \& Environment, 1-15. doi: 10.1007/s11111-011-0145-1

[65]Authority, Alaska Energy. (2015). Power Cost Equalization Program, Statistical Data by Community, Amended. Anchorage, AK. 
[66]Colt, S., Goldsmith, S., Wiita, A., \& Foster, M. (2003). Sustainable Utilities in Rural Alaska: Final report. Prepared for USDA Rural Development and Alaska Science and Technology Foundation.

[67]Schwörer, Tobias and Ginny Fay. "The Cool 100 Book." edited by James Haselip and David Pointing. Roskilde, Denmark: UNEP Ris $\varnothing$ Centre on Energy, Climate and Sustainable Development, 2011.

[68]Chapman, RN. (1996). Hybrid Power Technology for Remote Military Facilities. Proceedings for Power Quality Solutions/Alternative Energy, 415-427.

[69]DeMarban, Alex. (2011, November 30th). Nome Faces Energy Crisis in Wake of Bering Sea Storm, Alaska Dispatch News.

[70]Murphy, Kim. (2011, December 2nd). Ice Halts Delivery of Winter Fuel to Nome, Alaska, Los Angeles Times.

[71]Lipman, Don. (2012, January 18th). Nome Weather-Related Crisis Averted, for Second Time in History, The Washington Post.

[72] Loring, Philip A., \& Gerlach, S. Craig. (2009). Food, Culture, and Human Health in Alaska: an Integrative Health Approach to Food Security. Environmental Science \& Policy, 12, 466-478.

[73]Simon, Mallory. (2009). In Rural Alaska Villages, Families Struggle to Survive, CNN. Retrieved from http://www.cnn.com/2009/US/02/09/rural.alaska.villages/index.html?iref=storysearch

[74]Saylor, Ben, Haley, Sharman, \& Szymonkiak, Nick. (2008). Estimated Household Costs for Home Energy Use, May 2008 (Vol. Note No. 1). Anchorage, AK: Institute of Social and Economic Research.

[75]Holling, C.S. (1986). Resilience of Ecosystems: Local Surprise and Global Change. In W. C. Clark \& R. E. Munn (Eds.), Sustainable Development and the Biosphere. Cambridge, UK: Cambridge University Press.

[76]Chapin III, FS, Peterson, G., Berkes, F., Callaghan, TV, Angelstam, P., Apps, M., ... Danell, K. (2004). Resilience and vulnerability of northern regions to social and environmental change. AMBIO: A Journal of the Human Environment, 33(6), 344-349. doi: 10.1579/0044-7447-33.6.344

[77]Demer, Lisa. (2014, November 15th). Power Restored to Tuluksak, Alaska Dispatch News.

[78]Demer, Lisa. (2014, November 11th). Residents of Western Alaska Village without Power since Friday, Alaska Dispatch News.

[79]The Associated Press. (2016, January 22). Power Restored to Newtok after Days-Long Outage, Juneau Empire. Retrieved from http://juneauempire.com/state/2016-0121/power-restored-newtok-after-days-long-outage

[80]Sen, Amartya. (1999). Development as Freedom. New York, NY: Alfred A. Knopf, a division of Random House, Inc.

[81]ACEP. (2012). Stranded Renewable Energy Resources of Alaska: A Preliminary Overview of Opportunities and Challenges to Development. The National Renewable Energy Laboratory prepared by The Alaska Center for Energy and Power.

[82]Cold Climate Housing Research Center. (2010). Sustainable Northern Shelter Program. Fairbanks, AK: Cold Climate Housing Research Center.

[83]DeMarban, Alex. (2012, May 2nd). Wind Power Fuels Alaska's Push for Rural Renewable Energy Sources, Alaska Dispatch News. 
[84]U.S. Energy Information Administration, (EIA). (2015, June 19, 2014). Alaska State Profile and Energy Estimates. Retrieved April 1st, 2015, from http://www.eia.gov/state/analysis.cfm?sid=AK

[85]Project, REAP - Renewable Energy Alaska.). Alaska's Renewable Energy Projects. Retrieved April 1st, 2015, from http://alaskarenewableenergy.org/why-renewableenergy-is-important/alaskas-renewable-energy-projects/

[86]The Alaska State Legislature. (2010). State Energy Policy House Bill 306: 26th Legislature.

[87]Marsik, Tomas. (2016, January 7, 2016). Energy Literacy Yield Extraordinary Financial Returns while Helping the Planet, Commentary, Alaska Dispatch News. Retrieved from http://www.adn.com/article/20160107/energy-literacy-yields-extraordinary-financialreturns-while-helping-planet 